
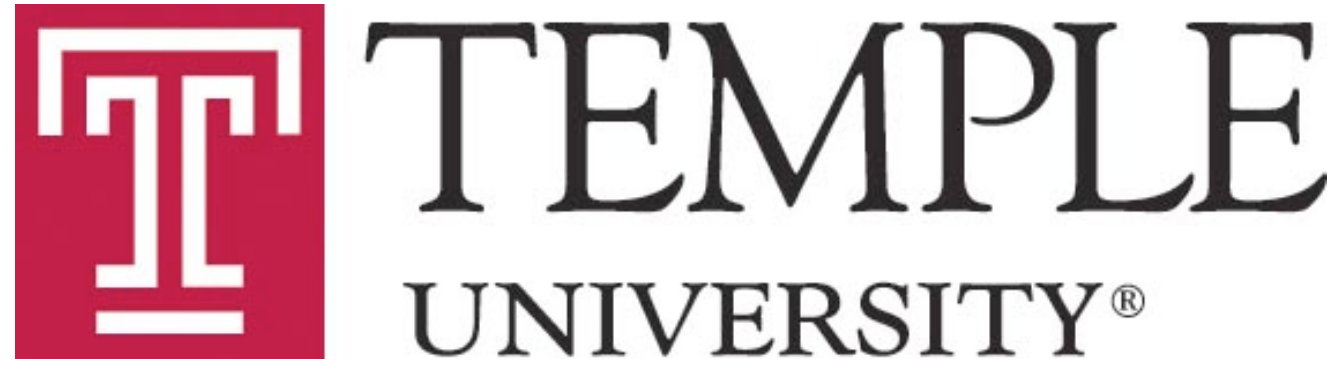

\title{
The Responses of the Prime Rate to a Change in Policies of the Federal Reserve
}

\author{
by \\ Joseph Friedman \\ Department of Economics \\ Temple University \\ jfriedman@temple.edu \\ Yochanan Shachmurove \\ City College of New York \\ New York, NY \\ yochanan@ssc.upenn.edu
}

Department of Economics

DETU Working Paper 14-05

September 2014

1301 Cecil B. Moore Avenue, Philadelphia, PA 19122

http://www.cla.temple.edu/economics/faculty/detu-working-paper-series/ 
The Responses of the Prime Rate to a Change in Policies of the Federal Reserve

\author{
Joseph Friedman* \\ Temple University \\ Philadelphia, PA \\ jfriedman@temple.edu \\ And \\ Yochanan Shachmurove \\ City College of New York \\ New York, NY \\ yochanan@ssc.upenn.edu
}

*Corresponding Author 


\title{
The Responses of the Prime Rate to a Change in Policies of the Federal Reserve
}

Joseph Friedman and Yochanan Shachmurove

\begin{abstract}
This paper studies the reactions of commercial banks to the changes in monetary policy tools in mid-1994, when the Federal Reserve Bank altered its policy implicitly targeting the Federal Funds Rate (FFR). Prior to 1994, the FFR had affected, with a considerable lag, the Prime Rate. However, after the move by the Fed in 1994, commercial banks responded immediately by changing their Prime lending rate to the Federal Funds Rate plus a three-percent spread. Based on the response of commercial banks, it is evident that a more transparent monetary policy can, in fact, more effectively achieve its underlying objectives.
\end{abstract}

JEL Classification: C15, C32, C58, E00, E4, E5, G00, G2, G38

Key Words: Federal Fund Rate; Prime Rate; Federal Reserve Bank; Monetary Policy; Commercial Banks; Vector Auto Regression (VAR); Vector Error Correction (VEC); Interest Rate Targeting; Unit Root Tests; Granger Causality; Variance Decomposition;

Corresponding author: Joseph Friedman (jfriedman@temple.edu) 


\section{The Responses of the Prime Rate to a Change in Policies of the Federal Reserve}

\section{Introduction}

The prime interest rate is an important benchmark on which banks price their loans across a wide range of categories. While studies by Goldberg (1982) and Forbes and Mayne (1989) find that the prime rate is not responsive to changes in various cost-measures of bank funds in both downward and upward directions, a recent paper, by Zhu, Chen and Li (2009) find that since the early 1990s, the prime rate has become more responsive to changes in money market conditions.

More importantly, Zhu et al. show that responsiveness of the prime rate is independent of changes in market interest rates, but are reacting to the element of uncertainty associated with market interest rates. In their study, Zhu et al. (2009) investigate the responsiveness of the prime rate to variations in one-month Certificate of Deposits (CD) rates, which they use as a proxy to changes in money market conditions.

However, Zhu et al. (2009) ignore the possible influences of the Federal Funds Rate (FFR) on the responses of commercial banks. The FFR is an important money market indicator, perhaps the most important monetary policy tool used by the Federal Reserve Bank of the United States (FED). Since the second quarter of 1994, the Federal Reserve monetary policy has explicitly and publically targeted the FFR. Henceforth, this study offers an alternative to the study by Zhu et al. (2009) and analyzes how changes in FFR cause changes in the prime rate.

This paper shows that after 1994, when the FED had altered its monetary policy by openly setting the FFR, and as a response to such a move, commercial banks changed their behavior by setting the prime rate equal to the Federal Fund Rate plus a margin of three percent. Prior to 1994, banks had been less sensitive to policy changes by the FED. 
The paper is organized as follows: Section 2 presents a brief literature review. Section 3 presents the data, the modeling methods, and the statistical results. This section presents the results of both the Vector Auto-Regression (VAR) Estimation and the Vector Error Correction (VEC) models. Section 4 concludes.

\section{Literature Review}

Previous empirical studies, specifically those by Goldberg (1982) and Forbes and Mayne (1989), find that changes in prime rates are positively correlated with the changes in market interest rates and provide explanations for prime rate stickiness. According to Goldberg (1982), the prime rate is the average of banks' cost of current and outstanding liabilities, and thus changes to the banks' cost of funds imply changes in the prime rate. Goldberg also suggests that the prime rate adjustments lag behind the changes in banks' cost of loanable funds. The lag is attributed to the unwillingness of banks to change the prime rate upon minor changes in money market conditions. However, Goldberg claims that the prime rate is sticky due to banks' fears that their prices would fail to match in case the interest rate increases.

Forbes and Mayne (1989), in an attempt to explain prime rate stickiness, provide a discussion of a friction model for the prime rate. They identify a threshold that must be met for the prime rate to change with market interest rates. Unlike Goldberg (1982), Forbes and Mayne (1989) focus on current interest rates rather than lagged ones.

Zhu, et al. (2009) study the prime rate responsiveness in a recent paper. The Prime rate, used by banks in lending decisions, has been widely considered to be responsive to the changes in the marginal costs of bank funds, see Goldberg, op cit. and Forbes and Mayne, op cit., but Zhu, et al. (2009) provide evidence to the contrary. They claim that the prime rate is independent of the movement of interest rates. The argument that prime rate is related to uncertainty of 
market interest rates is inconsistent with the preexisting literature on the topic. Zhu, et al. (2009) find that prime rate has become more responsive to changes in market interest rates. They also conclude that these changes are correlated with the uncertainty of interest rates rather than the actual changes in the interest rates.

Using time series data for a period of four-decades (1965-2006), along with the econometric models used by Hafer (1983), Goldberg (1984), and Levine and Loeb (1989), Zhu, Chen and Li (2009) explore the discrepancies in the literature. Instead of partitioning their study into two groups: UPs or DOWNs, based on one-month Certificate of Deposit (CD) rates from previous months, as it has been done in the past, Zhu, et al. (2009) split their sample into three sub-sample periods corresponding to the direction of long-term trends in the prime rate spread, which is the difference between the prime rate and the one-month CD rate.

The first period, which runs from May 1965 to April 1981, sees an upward trend in market interest rates. The second and third periods, from May 1981 to December 1990, and January 1991 to January 2006, respectively, show a downward trend in these rates. It should be noted that these authors ignore the important role of the federal funds rate in determining interest rates in the United States. Additionally, as we report in Section 3.2 below, Zhu, et al. (2009) claim that the interest rate series they used were stationary, while our tests indicate the opposite.

\section{Data and Results}

This study examines recent changes in the behavior of the prime rate in the United States. Since February 1994, the Federal Reserve has announced explicitly that its target for monetary policy would be the Federal Fund interest rate. Consequently, commercial banks changed the way they determined the prime rate. After 1994, banks adapted a simple formula that sets the prime rate to be equal to the Federal Fund Rate plus three percent. 
This paper analyzes changes in the behavior of the Prime Rate by utilizing two statistical methods, namely the Vector Autoregressive Approach (VAR) and the Vector Error Correction Model (VEC).

\subsection{Data}

The monthly data for this study consist of time series of the two types of rates, the Federal Fund Rate and the Prime Rate. The data for the Federal Fund Rate and the Prime Rate are obtained from the Federal Reserve Economic Data (FRED) database maintained by the Federal Reserve Bank of St. Louis. The entire period of the study is from January 1981 until December 2006.

\subsection{Unit Root Tests}

The VAR Model presupposes that time series are stationary. The two interest rates time series are tested with the use of the Augmented Dickey-Fuller (ADF), where the probabilities, reported in Table 1, are the MacKinnon (1996) one-sided p-values.

\section{Insert tables $1 \mathrm{a}$ and $\mathbf{1 b}$ here}

When estimated at the level of the variables, these tests reject the assumption that each variable has no unit root, implying that the relationships among the various variables, when analyzed in levels, are spurious. These results are in contrast to the test results reported by Zhu, et al. (2009). The non-stationary results dictate the use of either differencing the data in a Vector Auto Regression (VAR) model or the use of Vector Error Correction (VEC) models on the level of the data. This paper utilizes these two models. 


\subsection{Granger Causality Tests}

This section presents the Granger Causality tests for the data. Although causality tests ignore dynamic feedback effects, they are useful to set the scene. Table 2 reports the pair-wise Granger causality tests for the first differences in the variables for the first period (Period 1), namely May, 1981 until December, 1993, and for the second period (Period 2) February, 1994 to December, 2006. The variable DFFRATE denotes the first differences of the Federal Funds Rate and similarly, the variable DPRIME denotes the first differences in the Prime Rate.

In the first period, both DFFRATE and DPRIME cause each other. In the second period, however, the hypothesis that DPRIME does not Granger cause DFFRATE cannot be rejected, while DFFRATE clearly causes DPRIME. This result shows the increased influence of the Federal Funds Rate on the Prime Rate after the Fed changed its policy.

\section{Insert 2 about here}

\subsection{Vector Auto Regressions}

The decomposition of the forecast error variance for horizons of $1,6,12,18$ and 24 months ahead is presented in Table 3. For the first period, within the first six months, DPRIME affects 5 percent of DFFRATE, whereas the effect in the second period is a mere 1.55 percent. This pattern continues and after 24 months, DPRIME affects 6.7 percent of DFFRATE in Period 1, whereas it affects only 3.22 in Period 2. As far as the variance decompositions of DPRIME are concerned, in the first period, the effects of DFFRATE on DPRIME are 39 percent and increase to 70 percent after 24 months. However, the effects of DFFRATE on DPRIME are more prominent, 85 percent from the first month to 87.5 percent in the twenty-fourth month. 
This provides further evidence that banks have been more responsive to the monetary policy after the Federal Reserve became more transparent with regards to its interest rate targeting. The result clearly indicates that there was a major shift in the Fed's selection of its monetary policy instrument, and the commercial banks responded to this policy, as indicated by the FFRATE. These results are in line with the hypothesis advanced in this paper.

Insert Table 3 here

Turning to the figures depicting Monte Carlo simulations with 100 repetitions of the responses to Cholesky One Standard Deviation innovations where the dotted lines represent plusminus two standard deviations, Figure 1 shows the responses of DFFRATE and DPRIME to one standard deviation shocks. In periods 1 and 2, the responses of DFFRATE to DPRIME are not significant. In Period 1, the response of DPRIME to DFFRATE is positive and lasts only for about 6 months, whereas in Period 2, the response is more pronounced and continuous for more than a year.

Insert Figures 1 and 2

\subsection{The Vector Error Correction Model}

Table 4 presents the estimation result of the Vector Error Correction Model (VECM) for Period 1 and Period 2. For both periods, FFRATE and PRIME are co-integrated. For Period 1, the long- term relationship is:

PRIME $=2.8+$ FFRATE 
For Period 2, the long-term relation is:

PRIME $=3.0+$ FFRATE

Insert Table 4 Here

For both periods the Prime Rate (PRIME) is caused by the Federal Funds Rate (FFRATE) whereas FFRATE is not caused by PRIME. In terms of the speed of adjustment from deviations from the long-term equilibrium, one observes that the response is immediate in Period 2 (coefficient of 0.99), whereas in Period 1 the coefficient is only 17 percent per month.

In Period 1, the short-term relationship for both FFRATE and PRIME is significant and includes feedback effects to both changes in these variables. However, in Period 2, the commercial banks adapted a simple formula for determining the prime rate by merely charging a three-percent margin above the FFRATE. This is evident by observing that the coefficients of the lagged variables are significant for Period 1 but not significantly different from zero for Period 2 .

\section{Conclusions}

This paper shows that more transparency in the Federal Reserve monetary policy affected the commercial banks' reaction to changes in the Federal Fund Rate. This conclusion is based on the evidence that during Period 1, DFFRATE and DPRIME Granger cause each other, while during Period 2 DFFRATE Granger causes DPRIME but the hypothesis that DPRIME does not Grange cause DFFRATE cannot be statistically rejected. 
The analysis of the Variance Decompositions further supports this result. In Period 1, DFFRATE is only affected by DPRIME between 5.03\% and 6.69\% after 6 and 24 months, respectively. During the second period, the outcome is stronger, where DFFRATE affected by DPRIME fell between $1.55 \%$ and $3.22 \%$, after 6 and 24 months, respectively. However, the variance decomposition for DPRIME shows that the effect of DFFRAATE grew from 39\% to $85 \%$ after one month between Period 1 and Period 2. The same pattern holds after 24 months, being lesser extreme, where the effect of DFFRATE on DPRIME increases from $70 \%$ to $87.5 \%$ in Period 1 and Period 2, respectively.

Moreover, the paper finds that the Fed was more responsive to changes in FFRATE in Period 2 than in Period 1. The coefficients for the lagged variables in the first case are not significantly different from zero, while in the latter they are significant. In the long-term equilibrium, the response is immediate during Period 2, with a coefficient of 0.99 , while the coefficient is 0.169 during Period 1. After 1994, the Fed decided to define its prime rate simply as the Federal Fund Rate plus a 3 percent spread. Thus, the paper supports the hypothesis that more transparency by the Federal Reserve Bank has caused commercial banks to react more swiftly and accurately to the policies advanced by the monetary authority of the United States. 
$\underline{\text { Tables }}$

Table 1a: Unit Root Tests for Period 1, 1981:05 - 1993:12

\begin{tabular}{|l|r|r|}
\hline Null Hypothesis: Variable has a unit root & t-Statistic & Probability* \\
\hline & & \\
\hline Federal Funds & -2.65849 & 0.0838 \\
\hline & & \\
\hline Prime Rate & -2.16491 & 0.2201 \\
\hline & & \\
\hline $1^{\text {st }}$ Difference of Federal Funds Rate & -4.26554 & 0.0007 \\
\hline & & \\
\hline $1^{\text {st }}$ Difference of Prime Rate & -4.18761 & 0.001 \\
\hline
\end{tabular}

The null hypothesis is that the variable has a unit root. The t-statistic is the Augmented DickeyFuller test statistic where the critical values are -3.47367 for $1 \%,-2.88046$ for $5 \%$ and -2.57694 for $10 \%$ confidence level. Tests show that the null hypothesis cannot be rejected for the federal Funds Rate and for the Prime Rate but is rejected for the $1^{\text {st }}$ differences of these variables

Table 1b: Unit Root Tests for Period 2, 1994:2 - 2006:12

\begin{tabular}{|l|l|r|}
\hline Null Hypothesis: Variable has a unit root & t-Statistic & Probability* \\
\hline & & \\
\hline Federal Funds & -1.74497 & 0.4067 \\
\hline Prime Rate & & \\
\hline & -2.08733 & 0.2501 \\
\hline 1st Difference of Federal Funds Rate & -4.06586 & 0.0015 \\
\hline & & \\
\hline 1st Difference of Prime Rate & -4.06586 & 0.2501 \\
\hline
\end{tabular}

The null hypothesis is that the variable has a unit root. The t-statistic is the Augmented DickeyFuller test statistic where the critical values are -3.47367 for $1 \%,-2.88046$ for $5 \%$ and -2.57694 for $10 \%$ confidence level. Tests show that the null hypothesis cannot be rejected for the federal Funds Rate and for the Prime Rate but is rejected for the $1^{\text {st }}$ differences of these variables 


\section{Table 2: Pairwise Granger Causality Tests}

Sample: 1981:05 - 1993:12

\begin{tabular}{|l|r|r|r|}
\hline Null Hypothesis: & Observation & F-Statistic & \multicolumn{1}{l|}{ Probability } \\
\hline & & & \\
\hline $\begin{array}{l}\text { DFFRATE does not Granger Cause } \\
\text { DPRIME }\end{array}$ & 152 & 11.8692 & $9.00 \mathrm{E}-16$ \\
\hline $\begin{array}{l}\text { DPRIME does not Granger Cause } \\
\text { DFFRATE }\end{array}$ & & 2.42164 & 0.0073 \\
\hline
\end{tabular}

Sample: 1994:2 - 2006:12

\begin{tabular}{|l|r|r|r|}
\hline Null Hypothesis: & Observation & F-Statistic & Probability. \\
\hline & & & \\
\hline $\begin{array}{l}\text { DPRIME does not Granger Cause } \\
\text { DFFRATE }\end{array}$ & 155 & 0.58274 & 0.853 \\
\hline $\begin{array}{l}\text { DFFRATE does not Granger Cause } \\
\text { DPRIME }\end{array}$ & & 3.44381 & 0.0002 \\
\hline
\end{tabular}

DFFRATE: $1^{\text {st }}$ differences of the Federal Funds Rate

DPRIME: $1^{\text {st }}$ differences of the Prime Rate 
Table 3: Variance Decomposition

\begin{tabular}{|c|c|c|c|c|c|c|}
\hline \multirow{2}{*}{$\begin{array}{l}\text { Variance Decomposition of } \\
\text { DFFRATE: }\end{array}$} & \multicolumn{3}{|c|}{ Period 1: 1981:05 - 1993:12 } & \multicolumn{3}{|c|}{ Period 2: 1994:2 - 2006:12 } \\
\hline & & & & & & \\
\hline Period & S.E. & DFFRATE & DPRIME & S.E. & DFFRATE & DPRIME \\
\hline 1.00 & 0.40 & 100.00 & 0.00 & 0.14 & 100.00 & 0.00 \\
\hline & & 0.00 & 0.00 & & -1.90 & -1.90 \\
\hline 6.00 & 0.46 & 94.97 & 5.03 & 0.17 & 98.45 & 1.55 \\
\hline & & -3.44 & -3.44 & & -3.82 & -3.82 \\
\hline 12.00 & 0.47 & 93.73 & 6.27 & 0.19 & 97.10 & 2.90 \\
\hline & & -3.92 & -3.92 & & -4.43 & -4.43 \\
\hline 18.00 & 0.47 & 93.37 & 6.63 & 0.19 & 96.79 & 3.21 \\
\hline & & -4.29 & -4.29 & & -4.46 & -4.46 \\
\hline 24.00 & 0.48 & 93.31 & 6.69 & 0.20 & 96.78 & 3.22 \\
\hline & & -4.40 & -4.40 & & -4.47 & -4.47 \\
\hline $\begin{array}{l}\text { Variance Decomposition of } \\
\text { DPRIME: }\end{array}$ & & & & & & \\
\hline Period & S.E. & DFFRATE & DPRIME & S.E. & DFFRATE & DPRIME \\
\hline 1.00 & 0.23 & 39.04 & 60.96 & 0.12 & 84.99 & 15.01 \\
\hline & & -5.11 & -5.11 & & -3.24 & -3.24 \\
\hline 6.00 & 0.36 & 70.52 & 29.48 & 0.17 & 86.24 & 13.76 \\
\hline & & -5.11 & -5.11 & & -4.47 & -4.47 \\
\hline 12.00 & 0.37 & 69.56 & 30.44 & 0.19 & 87.39 & 12.61 \\
\hline & & -5.62 & -5.62 & & -5.00 & -5.00 \\
\hline 18.00 & 0.37 & 70.06 & 29.94 & 0.19 & 87.30 & 12.70 \\
\hline & & -6.10 & -6.10 & & -5.07 & -5.07 \\
\hline 24.00 & 0.37 & 70.01 & 29.99 & 0.20 & 87.50 & 12.50 \\
\hline & & -6.16 & -6.16 & & -5.09 & -5.09 \\
\hline
\end{tabular}


Table 4: Vector Error Correction Model

\begin{tabular}{|c|c|c|c|c|}
\hline Sample: 1981:05 - 1993:12 & & & $\begin{array}{l}\text { Sample: } 1994: 2- \\
2006: 12\end{array}$ & \\
\hline $\begin{array}{l}\text { Included observations: } \\
152\end{array}$ & & & $\begin{array}{l}\text { Included observations: } \\
155\end{array}$ & \\
\hline $\begin{array}{l}\text { Standard errors in ( ) \& t- } \\
\text { statistics in [ ] }\end{array}$ & & & $\begin{array}{l}\text { Standard errors in () \& } \\
\text { t-statistics in [ ] }\end{array}$ & \\
\hline Cointegrating Equation & & CointEq1 & CointEq1 & \\
\hline PRIME(-1) & & 1 & 1 & \\
\hline \multirow[t]{3}{*}{ FFRATE(-1) } & & -0.955 & -1.001 & \\
\hline & & -0.036 & -0.003 & \\
\hline & & {$[-26.5033]$} & {$[-342.530]$} & \\
\hline $\mathrm{C}$ & & -2.460 & 2.996 & \\
\hline Error Correction: & D(FFRATE) & D(PRIME) & D(FFRATE) & $\mathrm{D}$ (PRIME) \\
\hline \multirow[t]{3}{*}{ Error Correction Term } & -0.082 & -0.169 & 0.345 & 0.987 \\
\hline & -0.070 & -0.043 & -0.289 & -0.239 \\
\hline & {$[-1.17]$} & {$[-3.940]$} & [1.197] & [4.13] \\
\hline \multirow[t]{3}{*}{$\mathrm{D}(\operatorname{PRIME}(-1))$} & -0.442 & -0.110 & 0.211 & 0.266 \\
\hline & -0.118 & -0.072 & -0.237 & -0.196 \\
\hline & {$[-3.743]$} & {$[-1.518]$} & {$[0.890]$} & {$[1.356]$} \\
\hline \multirow[t]{3}{*}{ D(FFRATE(-1)) } & 0.635 & 0.484 & 0.361 & 0.271 \\
\hline & -0.102 & -0.062 & -0.203 & -0.169 \\
\hline & {$[6.248]$} & {$[7.759]$} & {$[1.775]$} & {$[1.608]$} \\
\hline \multirow[t]{3}{*}{ Constant } & -0.071 & -0.045 & 0.006 & 0.007 \\
\hline & -0.037 & -0.023 & -0.012 & -0.010 \\
\hline & {$[-1.897]$} & {$[-1.9754]$} & [0.499] & {$[0.694]$} \\
\hline Adj. R-squared & 0.278 & 0.559 & 0.382 & 0.573 \\
\hline F-statistic & 20.342 & 64.711 & 32.667 & 69.762 \\
\hline Log likelihood & -91.467 & -17.385 & 83.298 & 112.504 \\
\hline
\end{tabular}




\section{Figures}

\section{Period 1}

Response to Cholesky One S.D. Innovations \pm 2 S.E.

Response of DFFRATE to DFFRATE

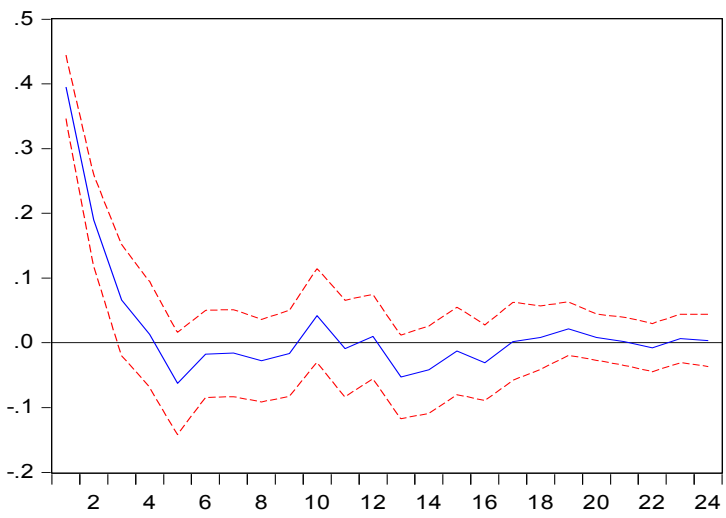

Response of DPRIME to DFFRATE

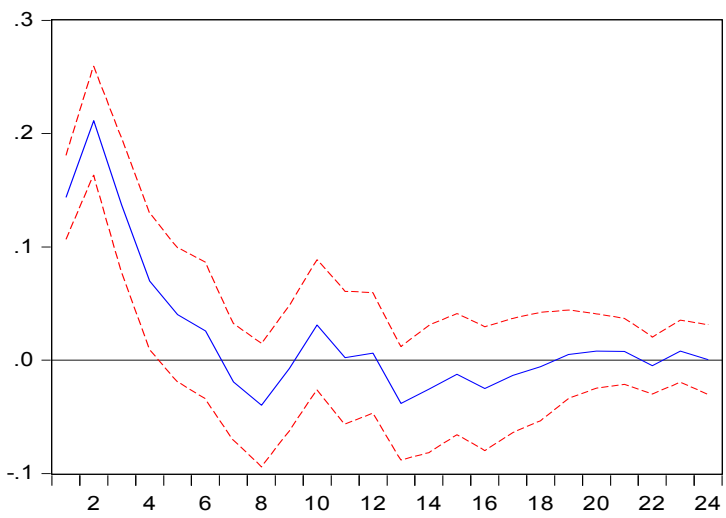

Response of DFFRATE to DPRIME

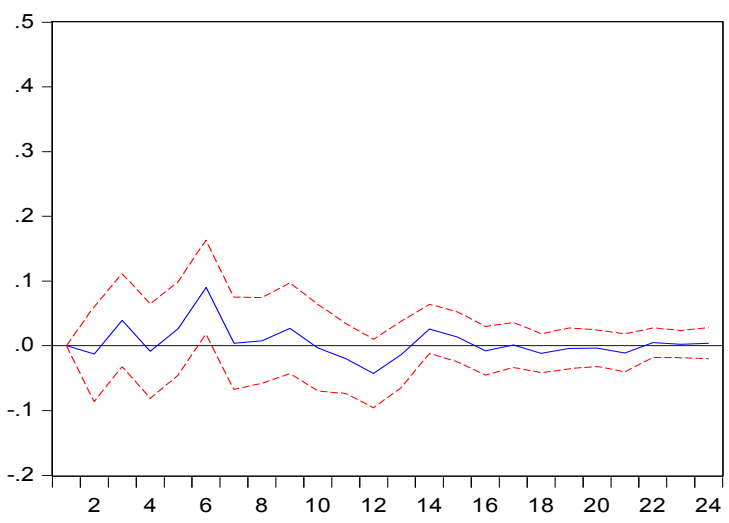

Response of DPRIME to DPRIME

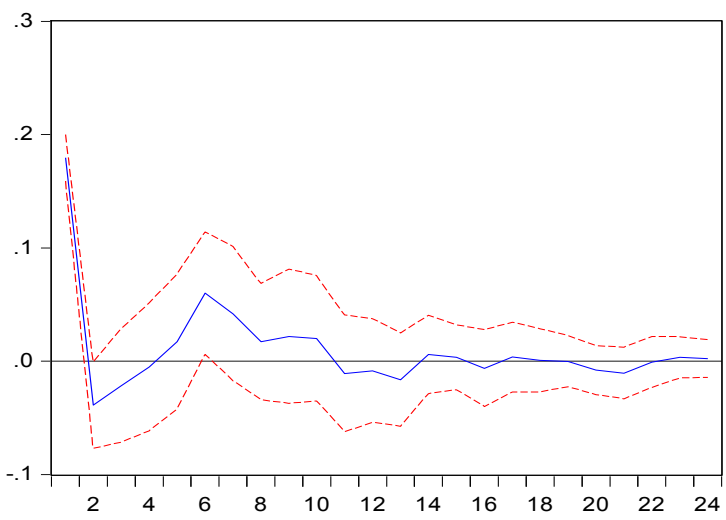




\section{Period 2}

Response to Cholesky One S.D. Innovations \pm 2 S.E.

Response of DFFRATE to DFFRATE

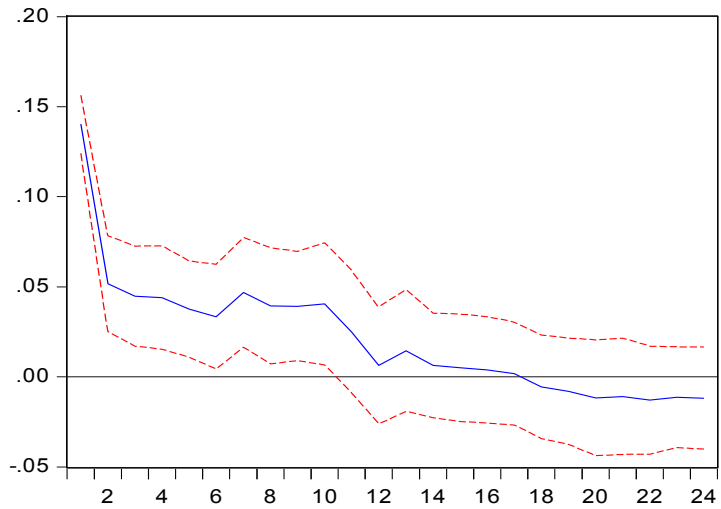

Response of DPRIME to DFFRATE

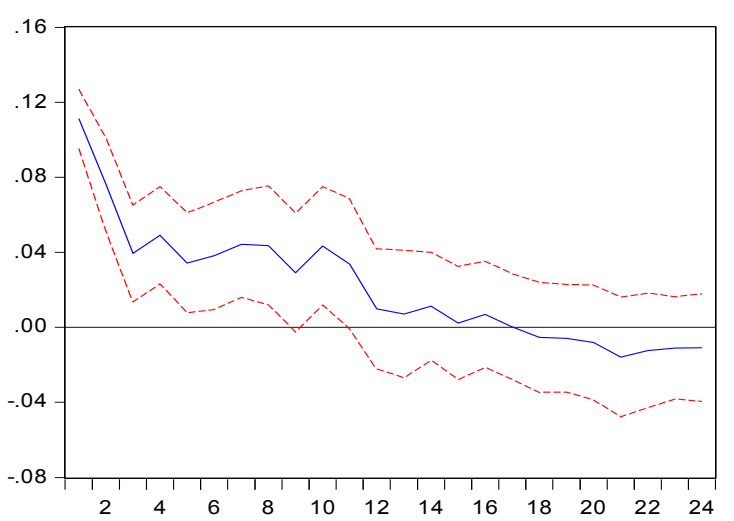

Response of DFFRATE to DPRIME

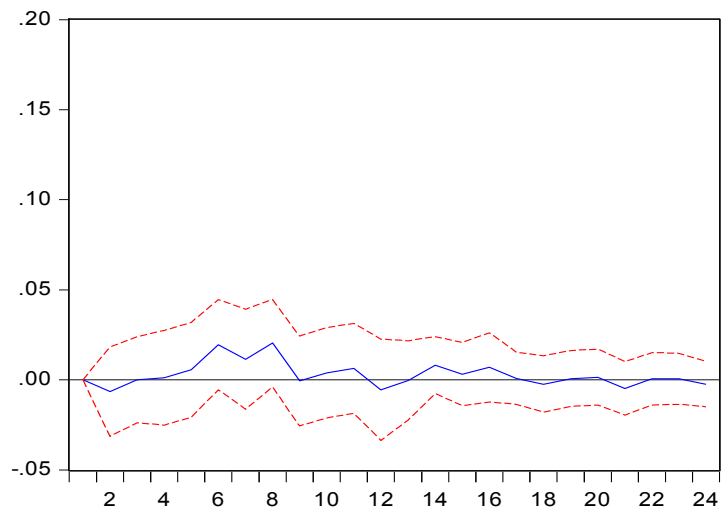

Response of DPRIME to DPRIME

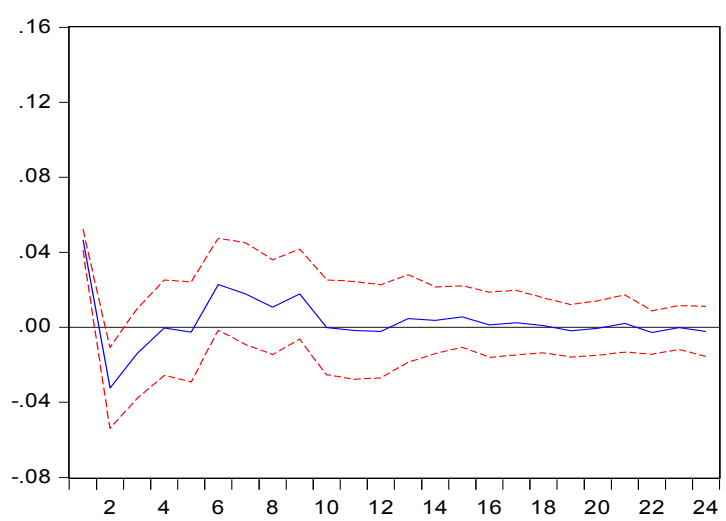




\section{REFERENCES}

Chen, Manfen W., Wanli Li, and Jianzhou Zhu. 2009. "Recent Changes in the Prime Rate Behavior." Review of Quantitative Finance and Accounting, 33: 177-192.

Forbes, Shawn M., and Lucille S. Mayne. 1989. "A Friction Model of the Prime." Journal of Banking and Finance, 13: 127-135.

Golberg, Michael A. 1982. "The Pricing of the Prime Rate." Journal of Banking and Finance, 6: 277-296.

Golberg, Michael A. 1984. "The Sensitivity of the Prime Rate to Money Market Conditions." Journal of Financial Services Research, 7: 269-280.

Hafer, Rik W. 1983. "The Prime Rate and the Cost of Funds: Is the Prime Too High?" Federal Reserve Bank of St. Louis Review, 65(5): 17-21.

Levine, P., and P. D. Loeb. 1989. "Asymmetric Behavior of the Prime Rates of Interest." American Economic Review, 33: 34-38.

MacKinnon, James. (1996), "Numerical distribution functions for unit root and co-integration tests," Journal of Applied Econometrics, 11, 601-618. 